\title{
Language Learning Strategies Used by Secondary Schools Students in Enhancing Speaking Skills
}

\author{
Nur Yasmin Khairani Zakaria1, Siti Nazima Zakaria1, Nora Ezzati Azmi² \\ ${ }^{1}$ Faculty of Education, The National University of Malaysia, Bandar Baru Bangi, Malaysia \\ ${ }^{2}$ UNIKL NAFAS Centre for Preparatory Study (CPS), Kota Damansara, Malaysia \\ Email: yasminzakaria@ukm.edu.my,nazimazakaria@gmail.com,nora@nafas.com.my
}

How to cite this paper: Zakaria, N. Y. K., Zakaria, S. N., \& Azmi, N. E. (2018). Language Learning Strategies Used by Secondary Schools Students in Enhancing Speaking Skills. Creative Education, 9, 2357-2366. https://doi.org/10.4236/ce.2018.914176

Received: August 16, 2018

Accepted: October 28, 2018

Published: October 31, 2018

Copyright (c) 2018 by authors and Scientific Research Publishing Inc. This work is licensed under the Creative Commons Attribution International License (CC BY 4.0).

http://creativecommons.org/licenses/by/4.0/ (c) (i) Open Access

\begin{abstract}
Mastering English as the second language has been a constant challenge for speakers of other languages. Malaysians, especially school students who are from sub-urban and rural areas are persistently struggling to fulfill the demands of becoming competent English language speakers. Students' low self-confidence and unfamiliarity with language structures hinder their potential to improve their speaking skills. Hence, there is a need to discover the students' most preferred strategies to enhance their speaking skills and refine the strategies to be further employed by the students. In this study, the researchers aim to: 1) identify the most frequently used strategies among secondary school students to enhance their speaking skills and, 2) analyse if there is any difference on the use of strategies among genders. Mixed-method approach was employed to answer the research questions. 60 secondary school students from a sub-urban area participated in the survey and six students volunteered to be the participants in a semi-structured interview. Oxford's SILL Questionnaire was adapted and translated into the respondents' native language and SPSS 7.0 version was used for data analysis. Results in this study revealed that practicing strategies are the most frequently used strategies and female students showed higher tendency to employ the strategies to enhance their speaking skills. The study suggests more integration of other strategies to be employed in language classroom such as metacognitive strategies, compensation and communication strategies to improve their language competency.
\end{abstract}

\section{Keywords}

Language Learning Strategies, Speaking Skills, ESL, Secondary School Students 


\section{Introduction}

From being the medium of instruction in education system during colonial times, English was relegated to being taught in schools as a second language. The change of role and status of English has drastically affected Malaysians' proficiency in the language (Gill, 2005). It affects not only writing skills, but also reading, listening and speaking among the students. In speaking, one of the constantly discussed areas is the use of language learning strategies to enhance speaking skills. In Malaysian education context, the status of English as a second language has affected the language learning process itself.

Earlier LLSs studies revolve around the identification of strategies used by successful learners to improve their English proficiency (Rubin, 1975; Razak \& Babikkoi, 2014). This is because the success of language learning tremendously depends on the learners' initiatives. Rubin (1975) added that successful language learners often possess active language learning process and progressively engaged towards their language proficiency. Rubin (1975) proposed that language learning strategies should be defined as "the learner's strategies" or "the strategies employed by the learners". LLSs can be defined as frequent steps or actions taken consciously by learners to improve the information transfer (Razak \& Babikkoi, 2014: Sociology Mind, 4(02), 206). Bialystok (1978) mentioned that LLSs are the ways that one uses to exploit the information in improving his proficiency on second language (1978). However, later definitions of LLSs focus on the learning process compared to learning product earlier on. The shift of the definition has changed from emphasising the improvement of language to facilitation the language learning (Mat Teh \& Embi, 2010; Noor, Yusoff, Yasim, \& Kamarudin, 2016).

It has been a debate among scholars regarding strategies commonly used by successful language learners. Yazdi \& Kafipour (2014) found out that good language learners are more or less conscious of emotional problems. As for Oxford (2016), she believes that emotions can affect one's learning process. Despite of the differences, few scholars agree that the ability to use the target language in a real communication is the key element of successful language learners (Rubin, 1975; Stern, 1975). Some of the main strategies include; active involvement in the task assigned, perceive language as a system, regard language learning as a process of communication and interaction, manage their emotions and affective skills effectively and lastly, evaluate their performance in the target language.

Students with sufficient English vocabulary can be regarded as competent users of English. Their ability to perform well in English language subject may be due to socioacademic status of the parents as well as the motivation gained from the teachers (Chai, Wong, \& King, 2016). Regardless of the successful students' ability to ace their language competency, there are quite a number of students who disregard the strategies to employ. In a study conducted by previous researcher, it was found that Malay students faced immense difficulties using the English language in writing, speaking, reading or understanding spoken English 
(Yazdi \& Kafipour, 2014). Apart from their general inability to interact meaningfully in English, they also faced problems in both accuracy and fluency while trying to use the language in the classroom (Chen, 2016). The same occurrence happened to a rural area school where the students are mainly Malays. Therefore, the researcher conducted a study to identify the language learning strategies used by the students from suburban area school and analyse the most frequent strategies employed by the students.

Generally, students from sub-urban and rural areas committed more language errors which resulted in their incompetence in the target language (Vrettou, 2011). In a Malay setting school with diverse socioeconomic status of the parents, the students depicted unsatisfactory performance of English language as well as other subjects. The primary reason that contributes to the students' inability to perform in English language is due to insufficient exposure about language learning strategies (Griffiths \& Oxford, 2014). Infrequent usage of language learning strategies resulted due to students' ignorance of the effectiveness of the strategies in order to be a successful language learner. Hence, this study aims to identify the LLSs used by students in order to improve their English speaking skills.

The researcher in the current study chose a school in suburban as the proficiency of the students is almost stagnant over the years. Students in the chosen setting do not possess decent knowledge background in language acquisition namely English. Most of the students are unfamiliar with the fundamental strategies to master the target language. One of the crucial aspects that remain stagnant is the number of successful male students in the compound that is decreasing over the years (Chen, 2016). The number of failures in English language test is surpassed by male students. It is crucial for the ESL learners to master language learning strategies in developing the proficiency in L2. Thus, a fundamental objective of the study lies on the relatedness of language learning strategies and students' proficiency in English. Hence, there is a need for more studies related to language learning strategies and their relation to students' proficiency in English. In this study, two research objectives were formulated:

1) To investigate preferred language learning strategies used by students to enhance their speaking skills and,

2) To analyse differences of language learning strategies used by male and female students to enhance their speaking skills.

\section{Methodology}

The current study employed a mixed-method research design comprising of data obtained from a survey questionnaire adapted from Oxford and semi-structured interview with the participants. The quantitative data in the study was collected using Language Strategy Use Survey adapted by O'Malley \& Chamot (1990), Cohen et al. (2005), Stern (1992) and Macaro (2001) and semi-structured interview was guided with an interview protocol adapted from Yin (2008). In this 
study, 60 form four students from a secondary school located in Bandar Baru Bangi were randomly selected to participate in this study. These students were from different classes and possess different levels of proficiency in English.

The study aims at identifying the use of language learning strategies among secondary school learners to enhance their speaking skills. Therefore, it is crucial to discover the most frequently used speaking skills strategies by the learners. The overall frequency was calculated from the primary data collected in the questionnaires distributed. Items in the questionnaire were analysed using Statistical Package for the Social Science (SPSS) 22 using descriptive analyses and t-test.

\section{Data Collection and Analysis}

Data were collected to investigate the preferred strategies used by the students in enhancing their speaking skills. Distribution of questionnaire for quantitative data was carried out according to the respondents' convenience and completed questionnaires were returned to the researchers on the same day. Apart from that, semi-structured interview sessions were conducted individually to six students who have volunteered to be a part of the participants. Consent forms were enclosed together with the questionnaires distributed in advance.

Data from the questionnaire were gathered, quantified and presented in the form of computed frequencies, means and standard deviations. An independent $\mathrm{t}$-test was conducted to identify is there is a difference in terms of strategies used between male and female students. Semi-structured interviews were to six participants lasted for 1 - 2 hours. Verbatim transcription was employed to the data obtained. Analysis of data was carried out thematically and students' responses were recorded and presented in categorical manner. In conducting qualitative study, trustworthiness is the most crucial aspect to be considered. Trustworthiness deals with credibility, transferability, dependability, and confirmability of the research (Merriam, 1998; Lincoln \& Guba, 1985). Few measures were taken into consideration by the researchers including validation of questions for semi-structured interview and peer validation.

\section{Findings}

The findings are presented according to research objectives as followed. The first part of the findings presented the most frequently used strategies to enhance speaking skills and the other part of discussion highlighted on the differences of language learning strategies use among genders.

\subsection{Frequently Used Strategies to Enhance Speaking Skills}

The first research question aims at identifying the most frequently used language learning strategies among secondary school students in a school located in Bandar Baru Bangi. Strategies to enhance speaking skills include practicing strategies, communication strategies and compensation strategies. The survey ques- 
tionnaire was adapted from Strategy Inventory for Language Learning (SILL) Version 7.0 by Oxford (1990). All items were translated into the respondents' native language, Malay Language, to avoid confusion and misunderstanding (Table 1).

From the analysis, it noted that practising strategies and compensatory strategies were the most frequently used strategies among the students. Practising strategies showed the highest mean which reflected that most used strategies by the students. However, the ranges of means were all rather close together (3.5 3.8). The values are rather close to the maximum value which is 5 . The results showed that most of the respondents answered between 3 - 5 which implied "agree" and "strongly agree". In practising strategies, two highly agreed statements are: 1) I say new expressions in English repeatedly to myself in order to practice them and 2) I am likely to practice new grammatical structures in different situations to check out my confidence level with the structures. The statements proved that the respondents are somewhat prefer to intrinsically use the language by practising it. The second frequently used strategy is compensatory strategy which is being depicted in the statement: 1) I often ask the person I $m$ talking with to help me out when $1 m$ having difficulties in communicating. The statement was purposely intended to evaluate the respondents' willingness to compensate with their difficulties upon facing unfamiliar words in a conversation.

Familiarity with the target language concerns with active communication in daily activities (Chen, 2016). From the interview, the respondents agreed that practising strategies are found to be the most effective strategies to improve their speaking skills. The students were also pointed out that speaking skills are very much related to producing the output. Some students (S2 and S3) pointed out that when they use the language more frequently, production of output (through speaking) became a lot easier and smoother. One of the students (S1) is a Youtuber and she mentioned that frequent practise in front of the camera through vlogging enables her to be more proficient in speaking. She also mentioned

Table 1. LLS used strategies used to enhance speaking skills.

\begin{tabular}{lccc}
\multicolumn{1}{c}{ Item } & Mean & SD & Frequency \\
\hline $\begin{array}{l}\text { I say new expressions in English repeatedly to myself } \\
\text { in order to practice them }\end{array}$ & 3.80 & 1.36 & High \\
$\begin{array}{l}\text { I am likely to practice new grammatical structures in different } \\
\text { situations to check out my confidence level with the structures }\end{array}$ & 3.90 & 0.70 & High \\
$\begin{array}{l}\text { I often ask the person I'm talking with to help me out when } \\
\text { I'm having difficulties in communicating. }\end{array}$ & 3.23 & 1.19 & Moderate \\
$\begin{array}{l}\text { I watch how a native speaker might say something and } \\
\text { I attempt to practice saying it that way. }\end{array}$ & 2.85 & 1.57 & Low \\
I watch how a native speaker might say something and & & & Moderate \\
I attempt to practice saying it that way & 3.61 & 1.30 & Low \\
I often look to others to correct my errors in speaking \\
and welcome the feedback.
\end{tabular}


that her speaking skills are gradually improving as she gets used to talking to the camera.

S1: I have Youtube channel for my vlogs. That is how I improve my speaking.

S2: It was hard... at first to speak... but after some time, you will be okay.

S3: Yes... practise is a must. If we want to be good in writing, we should write more... If speaking, we should speak more.

From the interview, the students seem unaware of the strategies. After being explained about the strategies, the students agreed that compensation strategy is also one of the most frequently used strategies to improve their language skills. Compensation strategies are often being used when communicating with foreigners. Willingness to compensate one's inability is also a strategy to improve fluency in speaking (Amir, 2018). When asked about overcoming limitations in communication in the second language, the students (S5 and S6) mentioned that they often use mime of gesture to explain a situation.

S5: Usually when foreigners asked me. If I don't know the word, I tried to explain using hand (gestures) or show symbols (thumbs up if something is good). S6: When I watch English movies, I tried to understand and make sense (guess intelligently) it when I don't know the meaning. Especially if the movie don't have subtitles.

S4: Yes. use (practise)... always use (practise)... If not, we're not familiar to (used to) it.

Three least frequently used strategies which marked the means ranges from 2.5 - 2.9 have also been identified by the researchers. The strategies include a practising strategy and two communication strategies. The least frequently used practising strategy was identified in the statement: 1) I watch how a native speaker might say something and I attempt to practice saying it that way. The statement uncovers the geographical setting of the study which is in suburban school. Since the respondents rarely meet a native speaker of English, therefore it will be difficult for them to use the strategy to improve their English language speaking skills. Another least frequently used strategies are: 1) I often look to others to correct my errors in speaking and welcome the feedback. Being Malaysians, it has become a norm not to ask others to correct one's mistake (Noor, Yusoff, Yasim, \& Kamarudin, 2016). Therefore, the statement shows the respondents' perceptions towards other's comments and feedback.

\subsection{Differences of LLS Use among Genders}

The second objective of the study aims at analysing the differences of language learning strategies used between male and female students who participated in this study. Generally, the female students inclined to show more improvement and a higher performance in English language (Razak \& Babikkoi, 2014). In this study, the researchers discovered that the female students showed more desire in employing language learning strategies compared to male students during their conversations. A t-test was conducted in the current study using data obtained 
which consisted of the respondents marks in English subject and their preferred language strategies used. The level of significance was established at 0.005 . In Table 2, the mean value of female $(M=164.76)$ is higher than the scores of male students $(M=139.33)$. A figure is illustrated to show the graphic of mean values of both groups. In order to identify the relationship between gender and amount of language learning strategies employed, an independent samples t-test was used to the data.

As presented in Table 2, the differences of mean scores between two groups of students (female and male students) is significant $(\mathrm{M}=139.33, \mathrm{~F}=164.76)$. The standard deviation of group 1 (male students) is higher than the standard deviation of group 2 (female students). The smaller value of standard deviation scores among female students depicts a central tendency pattern of respondents. In other words, the female respondents' scores in frequency of using the language learning strategies were much higher compared to male group of respondents. The scores of language learning use frequency among male respondents were relatively inconsistent.

Levene's Test for Equality of Variances was used in the current study and the Sig. Value presented was 0.281 , which was greater than 0.05 . Therefore, it can be assumed that the variances were equal. As a result, it is possible to test the hypothesis using the Equal Variances Assumed row of the $t$-test in the aforementioned Table 3. This provided the $t$-value $(t=-5.119)$, the degrees of freedom $(d f=58)$, and sig. $(2$-tailed $)=0.001$, which is lower than .05 . As a result, it can be concluded that the difference in the use of LLS of males and females was significant; which indicates the fact that females $(M=164.76)$, on average, employed more LLS than males $(M=139.33)$. As a result, it can be concluded that,

Table 2. Group statistics of the male and female participants for LLS used.

\begin{tabular}{ccccc}
\hline \multicolumn{5}{c}{ Group Statistics } \\
\hline Gender & $\mathrm{N}$ & Mean & Std. Deviation & Std. Error Mean \\
\hline Male & 39 & 139.33 & 0.899 & 3.186 \\
Female & 21 & 164.76 & 0.976 & 3.268 \\
\hline
\end{tabular}

Table 3. Independent samples test.

\begin{tabular}{|c|c|c|c|c|c|c|c|c|c|c|}
\hline \multicolumn{11}{|c|}{ Independent Samples Test } \\
\hline & & \multicolumn{2}{|c|}{$\begin{array}{c}\text { Levene's Test for } \\
\text { Equality of Variances }\end{array}$} & \multicolumn{7}{|c|}{ t-test for Equality of Means } \\
\hline & & \multirow[t]{2}{*}{$\mathrm{F}$} & \multirow[t]{2}{*}{ Sig. } & \multirow[t]{2}{*}{$\mathrm{t}$} & \multirow[t]{2}{*}{ df } & \multirow{2}{*}{$\begin{array}{c}\text { Sig. } \\
\text { (2-tailed) }\end{array}$} & \multirow{2}{*}{$\begin{array}{c}\text { Mean } \\
\text { Difference }\end{array}$} & \multirow{2}{*}{$\begin{array}{l}\text { Std. Error } \\
\text { Difference }\end{array}$} & \multicolumn{2}{|c|}{$\begin{array}{l}95 \% \text { Confidence } \\
\text { Interval of the Difference }\end{array}$} \\
\hline & & & & & & & & & Lower & Upper \\
\hline \multirow{2}{*}{ Frequency } & $\begin{array}{l}\text { Equal variances } \\
\text { assumed }\end{array}$ & 1.186 & 0.281 & -5.119 & 58 & 0.001 & -25.429 & 4.967 & -35.371 & -15.486 \\
\hline & $\begin{array}{l}\text { Equal variances } \\
\text { not assumed }\end{array}$ & & & -5.571 & 51.570 & 0.001 & -25.429 & 4.564 & -34.589 & -16.268 \\
\hline
\end{tabular}


female students use more LLS to improve their English language proficiency compared to male students.

An independent-samples t-test was conducted to the frequency of language learning used between male and female students. The results showed that there was a significant difference between male $(M=139.33, S D=0.899)$ and female students $(M=164.76, \mathrm{SD}=0.976) ; \mathrm{t}(8)=-5.119, \mathrm{p}=0.001$. Female students are more inclined to employ more language learning strategies due to their higher motivation to learn. Result in this study is parallel to previous studies conducted to identify the differences in amount of language learning strategies employed between genders. Female learners also have tendency to use overall language learning strategies more often than males (Ansarin \& Zeynali, 2012). In the context of Japanese students, Hashimoto (2002) discovered that anxiety towards the second language hinders their motivation to generally improve their proficiency.

\section{Conclusion}

The two principal objectives of this study are to identify the language learning strategies that are frequently employed by Malay students from a sub-urban area, and analyse if there is any difference used between genders. Findings in the study revealed that students with a higher proficiency prefer to use a certain type of language learning strategies that may not be preferred by a lower proficiency language learner. However, the frequency and preferences of employing language learning strategies are the most significant factors that distinguish the proficiency of successful language learners and poor language learners. According to Aslan (2009), lower proficiency students deployed strategies less often than intermediate level students, who used strategies less frequently than upper level ones. In regards to any differences in terms of language learning used between genders, female language learners use language learning strategies more frequently and achieve better proficiency in the target language compared to male language learners. This is in line with Vrettou (2011) whom identified a significant difference in terms of achievement and the amount of language learning strategies used.

In this light, English teachers should introduce new strategies in learning a language by providing more activities and recommendation in planning, monitoring and evaluation the progress of a task given; if a student shows a preference for metacognitive strategies. Preparing for the task given includes the ability to skim and predict the main idea before the listening task. In addition, it is important for the teachers to identify the students' inclination of strategy use before implementing the strategies in learning a language. Student who shows a preference for cognitive strategies in improving their skills should be given adequate chances to mentally practise the given tasks. Students should be taught how to mentally make connection of the new knowledge with the previous information.

Every research, no matter how successfully planned and carried out, has cer- 
tain limitations. Hence, it is possible that further research considers and addresses these limitations. First, the researchers recommend the future study to be conducted in a school with more diversified proficiency of the students of different streams. Therefore, a prospective study may be useful for the researchers to identify the expected outcomes and difficulties that the students may face. Secondly, researchers recommend more detailed analysis and relationship to be conducted in analysing the students' inclination on using the language learning strategies. In-depth study towards the students' degree of liking English may contribute to the students' inclination and willingness to apply the language learning strategies in improving their English language proficiency. Lastly, the researcher suggested a thorough analysis of the effectiveness of the language learning strategies used and the students' performance in English. A pre-test and post-test study also provided an added value and information to the researcher to assess whether the implementation of language strategies has a positive influence on students' performance in English language.

\section{Conflicts of Interest}

The authors declare no conflicts of interest regarding the publication of this paper.

\section{References}

Amir, M. (2018). Language Learning Strategies Used by Junior High School EFL Learners. LLT Journal: A Journal on Language and Language Teaching, 21, 94-103.

Ansarin, A. A., \& Zeynali, S. (2012). Exploring the Gender Effect on EFL Learners' Learning Strategies. Theory \& Practice in Language Studies, 2. https://doi.org/10.4304/tpls.2.8.16141620

Aslan, O. (2009). The Role of Gender and Language Learning Strategies in Learning English. MA Thesis, Kizilay: Middle East Technical University.

Bialystok, E. (1978). A Theoretical Model of Second Language Learning. Modern Language Journal, 28, 69-83.

Chai, C. S., Wong, L. H., \& King, R. B. (2016). Surveying and Modeling Students' Motivation and Learning Strategies for Mobile-Assisted Seamless Chinese Language Learning. Journal of Educational Technology \& Society, 19, 170.

Chen, Z. (2016). Language Learning Strategies Based on the Educational Concept of Innovation and Entrepreneurship. Open Access Library Journal, 3, 1.

Cohen, A. D. (2005). Language Learning Strategy Instruction: Current Issues and Research. Annual Review of Applied Linguistics, 25, 112-130.

Gill, S. K. (2005). Language Policy in Malaysia: Reversing Direction. Language Policy, 4, 241-260. https://doi.org/10.1007/s10993-005-7859-9

Griffiths, C., \& Oxford, R. L. (2014). The Twenty-First Century Landscape of Language Learning Strategies: Introduction to This Special Issue. System, 43, 1-10. https://doi.org/10.1016/j.system.2013.12.009

Hashimoto, Y. (2002). Motivation and Willingness to Communicate as Predictors of Reported L2 Use: The Japanese ESL Context. Second Language Studies, 20, 29-70.

Lincoln, Y. S., \& Guba, E. G. (1985). Naturalistic Inquiry(Vol. 75). Sage. 
Macaro, E. (2001). Learning Strategies in Foreign and Second Language Classrooms: The Role of Learner Strategies. Edinburgh: A\&C Black.

Mat Teh, K. S., \& Embi, M. A. (2010). Strategi pembelajaran bahasa. Kuala Lumpur: Penerbit Universiti Malaya.

Merriam, S. B. (1998). Qualitative Research and Case Study Applications in Education. Revised and Expanded from "Case Study Research in Education". San Francisco, CA: Jossey-Bass Publishers.

Noor, Z. A. M., Yusoff, N. M. R. N., Yasim, I. M. M., \& Kamarudin, M. Y. (2016). Foreign Language Vocabulary Learning Strategies in Malaysia. Creative Education, 7, 428. https://doi.org/10.4236/ce.2016.73042

O’Malley, J. M., \& Chamot, A. U. (1990). Learning Strategies in Second Language Acquisition. Cambridge: Cambridge University Press. https://doi.org/10.1017/CBO9781139524490

Oxford, R. (1990). Language learning Strategies (p. 3). New York.

Oxford, R. L. (2016). Teaching and Researching Language Learning Strategies: Self-Regulation in Context. Abingdon-on-Thames: Routledge.

Razak, N. Z. B. A., \& Babikkoi, M. A. (2014). English Language Learning Strategies of Malaysian Secondary School Students: Implication for Inter-Cultural Communication. Sociology Mind, 4, 206. https://doi.org/10.4236/sm.2014.42020

Rubin, J. (1975). What the Good Language Learner Can Teach Us. TESOL Quarterly, 9, 41-51. https://doi.org/10.2307/3586011

Stern, H. H. (1975). Wan Can We Learn from the Good Language Learners? Canadian Modern Language Review, 31, 304-318. https://doi.org/10.3138/cmlr.31.4.304

Stern, H. H. (1992). Issues and Options in Language Teaching. Oxford: Oxford University Press.

Vrettou, A. (2011). Patterns of Language Learning Strategy Use by Greek-Speaking Young Learners of English. Ph.D. Thesis, Thessaloniki: Aristotle University of Thessaloniki.

Yazdi, M., \& Kafipour, R. (2014). A Qualitative Study of Vocabulary Learning Strategies Applied by Iranian Undergraduate EFL Learners in Real Learning Setting. English Language Teaching, 7, 1. https://doi.org/10.5539/elt.v7n7p1

Yin, R. K. (2008). Case Study Research: Design and Methods. Applied Social Research Methods Series, 5, 282. 